\title{
Use of biostimulants in elephant grass cv. Napier
}

\section{Uso de bioestimulantes em capim-elefante cultivar Napier}

\author{
Estela Pezenti ${ }^{1}$; Márcio dos Santos Pedreira2*; Sérgio Augusto de Albuquerque \\ Fernandes ${ }^{2}$; Moizéis Silva Nery2; André da Cunha Peixoto Vitor ${ }^{3}$; Abias Santos \\ Silva4; Bárbara Louise Pacheco Ramos ${ }^{3}$
}

Highlights

Increase in crude protein content with the use of bioregulators.

Structural change and canopy height increase with application of bioregulators. Increased rumen degradability of the studied forage.

\begin{abstract}
This study was developed to examine the growth, yield, chemical composition and in situ degradability of elephant grass cv. Napier (Pennisetum purpureum). Five spraying protocols with biostimulants were tested, namely, Control - no application; 1BR - bioregulator at seven days; 2BR - bioregulator at seven days + bioregulator and foliar fertilization at 20 days; 2BR2 - bioregulator at seven days + bioregulator and foliar fertilization at 20 days + ethylene inhibitor at 30 days; and 3BR - bioregulator at seven days + bioregulator and foliar fertilization at 20 days + ethylene inhibitor and bioregulator at 30 days. The grass was cut evenly at a height of $15 \mathrm{~cm}$ and harvested at 70 days of regrowth. The experimental area was divided into two blocks according to the slope. Ninety plots were used, totaling an area of 4,608 $\mathrm{m}^{2}$. Each plot was composed of four 4-m rows spaced $80 \mathrm{~cm}$ apart. Chemical composition, morphological traits and forage digestibility data were evaluated. The 3BR protocol, with more bioregulator-based applications, resulted in higher canopy (9.78\%) and stem (9.58\%) compared with control group. The 2BR and 2BR2 treatments provided a $6.5 \%$ higher stem than control treatment. The improvement in the nutritional value of Pennisetum purpureum cv. Napier was due to the $17.55 \%$ increase in crude protein (CP) content provided by protocol 3BR relative to control group. Treatments 2BR2 and 3BR improved the effective degradability of dry matter (DM). The application of biostimulant protocols increased the potential degradability of neutral detergent fiber (NDF) (+4.1\%), with the greatest response seen in treatment 2BR2 in comparison with control treatment. Biostimulant protocols

1 Dra in Animal Science, Universidade Estadual do Sudoeste da Bahia, UESB, Itapetinga, BA, Brazil. E-mail: estelapezenti@gmail.com

2 Profs. Drs., Department of Rural and Animal Technology, UESB, Itapetinga, BA, Brazil. E-mail: mpedreira@uesb.edu. br; sfernandes@uesb.edu.br; mnery@uesb.edu.br

3 M.Sc. in Animal Science, UESB, Itapetinga, BA, Brazil. E-mail: acpv91@hotmail.com; agro.barbara@outlook.com

${ }_{4}$ Post-Doctorate Researcher, Empresa Brasileira de Pesquisa Agropecuária, EMBRAPA Gado de Leite, Juiz de Fora, MG, Brazil. E-mail: abias.severo@gmail.com

* Author for correspondence
\end{abstract}

Received: Apr. 01, 2021 - Approved: Oct. 11, 2021 
increase the canopy and stem heights and CP content. The application of a bioregulator associated with foliar fertilization and ethylene inhibitor improves the effective degradability of DM and NDF and the potential degradability of NDF in Pennisetum purpureum cv. Napier harvested at 70 days of regrowth.

Key words: Bioregulators. Degradability. Foliar fertilization. Micronutrients. Senescence.

\section{Resumo}

Objetivou-se avaliar o crescimento, a produtividade, a composição bromatológica e a degradabilidade in situ do capim-elefante cv. Napier (Pennisetum purpureum). Foram efetuados cinco diferentes protocolos de pulverização com bioestimulantes: Controle - nenhuma aplicação, 1BR - biorregulador aos 7 dias; 2BR - biorregulador aos 7 dias, biorregulador e adubação foliar aos 20 dias; 2BR2 - biorregulador aos 7 dias, biorregulador e adubação foliar aos 20 dias, inibidor de etileno aos 30 dias; 3BR - biorregulador aos 7 dias, biorregulador e adubação foliar aos 20 dias, inibidor de etileno e biorregulador aos 30 dias. Foi realizado o corte de uniformização do capim a 15 centímetros de altura, sendo a colheita efetuada aos 70 dias de rebrota. A área experimental foi dividida em dois blocos de acordo com a declividade. Foram utilizadas 90 parcelas, totalizando $4.608 \mathrm{~m} 2$ de área. Cada parcela foi composta por quatro linhas de quatro metros cada, com espaço entrelinhas de 80 centímetros. Os dados foram avaliados quanto à composição química, características morfológicas e digestibilidade da forragem. O protocolo 3BR, com mais aplicações à base de biorreguladores, resultou em dossel maior $(9,78 \%)$ e maior altura de caule $(9,58 \%)$ em relação ao grupo controle, bem como os tratamentos 2BR e 2BR2 promoveram aumento da altura de caule em $6,5 \%$ se comparado com tratamento controle. A melhoria no valor nutricional do Pennisetum purpureum cv. Napier se deu em função da elevação no teor de proteína bruta (PB) de 17,55\% em relação ao grupo controle com o protocolo 3BR. Houve aumento da degradabilidade efetiva da matéria seca (MS) para os tratamentos 2BR2 e 3BR. A aplicação dos protocolos de bioestimulantes aumentou a degradabilidade potencial da fibra em detergente neutro $(F D N)(+4,1 \%)$, com maior resposta para o tratamento 2 BR2 em relação ao tratamento controle. Os protocolos de bioestimulantes elevam a altura do dossel e do caule e incrementam o teor de PB. A aplicação de biorregulador, associado à adubação foliar e inibidor de etileno melhora a degradabilidade efetiva da MS e FDN e a degradabilidade potencial da FDN do Pennisetum purpureum cv. Napier cortado aos 70 dias de rebrota.

Palavras-chave: Adubação foliar. Biorreguladores. Degradabilidade. Micronutrientes. Senescência.

\section{Introduction}

Pennisetum purpureum cv. Napier has a high forage mass yield potential, which can reach about $25 \mathrm{t}$ dry matter ha ${ }^{-1}$ per harvest (Morais et al., 2009). Thanks to its vegetative propagation, this perennial crop has a low implementation cost. Its versatility in forms of use is attributed to direct grazing or the formation of forage to be supplied in its natural state or preserved in the form of silage and stored.

Topdressing with NPK-based formulations is performed between each harvest and regrowth cycle (Santos, 1993). However, when the plant requires a higher concentration of nutrients in the soil, foliar fertilization (macro-and micronutrients) can be used in view of the absorption and response time. In this way, possible mineral 
deficiencies can be corrected, thus increasing yield and the speed of growth (Harper, 1984; Mortate, Nascimento, Gonçalves, \& Lima, 2018). In this respect, the technology of biostimulant application associated with foliar fertilization has been adopted to increase yield. Biostimulants are a mixture of one or more bioregulators, or a mixture between bioregulators and other compounds of a different chemical nature, such as amino acids, vitamins and mineral salts, among others. They modify physiological processes of the plant changing its vital and structural processes, increasing production and improving its nutritional value (Caldas, Haridasan, \& Ferreira, 1990; Castro, Carvalho, Mendes, \& Angelini, 2017). Research reports indicate changes in plant yield and structure (Abrantes et al., 2011; Dantas, Queiroz, Vieira, \& Almeida, 2012; Ribeiro, Vieira, Girardi, Carvalho, \& Ribeiro, 2017). These studies were, however, developed on plants such as common bean, tamarind and tobacco, which belong to families distinct from grasses.

In grasses, biostimulants have been used and shown promising results: in maize, yield grew $13 \%$, and in sugarcane, by more than 20\% (Silva, Cato, \& Costa, 2010; M M. R. Ferreira, Ferreira, \& Bolonhezi, 2013; Cunha, Lima, Alvarez, Simon, \& Contardi, 2016; Pricinotto, Zucareli, Ferreira, Spolaor, \& Fonseca, 2019). However, in forage grasses, the study of biostimulants is still incipient, with the existing results obtained in species of the genus Brachiaria (Brennecke, Ferraz, \& Simões, 2015; Oliveira et al., 2019). In these studies, researchers found an increase in germination rate and root and shoot growth, as well as increases in dry matter accumulation rate. Nevertheless, in Pennisetum purpureum cv. Napier, there is a lack of data on the use of these substances. The use of bioregulators in the biostimulant protocol is aimed at increasing the supply of hormones to the plant, consequently activating enzymes that maintain growth metabolism active, delaying senescence.

In high-yielding forage plants, senescence is accompanied by changes in the chemical composition. This process is intensified by ethylene, which changes the proportion of potentially digestible components, increasing the cell wall (Chitarra \& Chitarra, 2005). Ethylene production is determined by the enzymes ACC synthase (1-aminocyclopropane-1carboxylate synthase) and ACC oxidase (1-aminocyclopropane-1-carboxylate oxidase). Thus, the inhibition of these enzymes is a determining factor for the reduction of ethylene production, which may increase longevity and delay senescence (Taiz \& Zeiger, 2017). In this scenario, the present study was undertaken to examine the action of biostimulants and associations via foliar spraying in increasing the yield, height, composition and nutritional aspects of Pennisetum purpureum cv. Napier harvested at 70 days of regrowth.

\section{Material and Methods}

The experiment was carried out with elephant grass (Pennisetum purpureum) on Fazenda Hera farm, in the municipality of Itapetinga - BA, Brazil (15¹5'12.48' S, $40^{\circ} 15^{\prime 19.78 " ~ W), ~ f r o m ~ M a r c h ~ 29 t h ~ t o ~ J u n e ~}$ 10th. The experimental project was approved by the Animal Use Ethics Committee at the State University of Southwest Bahia (approval no. 155/2017). 
According to the Brazilian Soil Classification System of the Empresa Brasileira de Pesquisa Agropecuária (EMBRAPA, 2006), the soil in the study area is classified as a eutric Red Yellow Ultisol, and according to the Köppen-Geiger classification, the climate of the region is tropical with a dry season (Aw). Temperatures in the period range from 21.4 to $29.4^{\circ} \mathrm{C}$ and precipitation between 750 and $1215 \mathrm{~mm}$ (Instituto Nacional de Meteorologia [INMET], 2019).

The experimental area was established on November 10, 2016, with stakes of up to three buds, in 15-cm-deep furrows. Ninety plots were used, totaling an area of 1,152 $\mathrm{m}^{2}$. The soil had the following physical-chemical attributes: $\mathrm{pH}$ in water $=5.8$; resin $\mathrm{P}=7 \mathrm{mg}$ $\mathrm{dm}^{-3} ; \mathrm{K}^{+}=0.18 \mathrm{cmolc} \mathrm{dm}^{-3} ; \mathrm{Ca}_{2}{ }^{+}=4.3 \mathrm{cmol} \mathrm{dm}^{-3}$; $\mathrm{Mg}_{2}{ }^{+}=2.9 \mathrm{cmol} \mathrm{dm}^{-3} ; \mathrm{Al}_{3}^{+}=0 \mathrm{cmolc} \mathrm{dm}{ }^{-3} ; \mathrm{H}^{+}$ $=2.2 \mathrm{cmol} \mathrm{dm}^{-3} ; \mathrm{Na}^{+}=0.06$ cmolc $\mathrm{dm}^{-3}$; sum

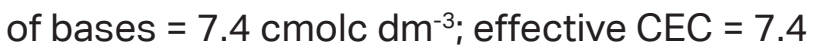
$\mathrm{cmol} \mathrm{dm}^{-3}$; CEC at pH $7.0=9.6 \mathrm{cmol} \mathrm{dm}^{-3}$; base saturation $=77 \%$; $E S P=1 \%$.

The uniformity cut of the grass was performed on March 29, 2017, at a height of $15 \mathrm{~cm}$. The experimental area was divided into two blocks according to the slope, with 90 plots of $16 \mathrm{~m}^{2}$, totaling 4,608 m2. Each plot was composed of four 4-m rows spaced $0.8 \mathrm{~m}$ apart. Total precipitation in the period was 198 $\mathrm{mm}$.

Topdressing was based on the recommendation of Santos (1993), with a total of $250 \mathrm{~kg} \mathrm{ha}^{-1}$ nitrogen (fertilizer urea; $45 \% \mathrm{~N}$ ), $300 \mathrm{~kg} \mathrm{ha}^{-1} \mathrm{~K}_{2} \mathrm{O}$ (potassium chloride; $60 \% \mathrm{~K}$ ) and $100 \mathrm{~kg} \mathrm{ha}^{-1} \mathrm{P}_{2} \mathrm{O}_{5}$ (single superphosphate; $18 \% \mathrm{P})$, which was broadcast in a single application after the uniformity cut.

Pennisetum purpureum cv. Napier was subjected to five spraying protocols with biostimulants (Tables 1 and 2) after tiller regrowth: Control - no application; 1BR - bioregulator at seven days; 2BR2 bioregulator at seven days + foliar fertilization at 20 days; 2BR3 - bioregulator at seven days + bioregulator and foliar fertilization at 20 days + ethylene inhibitor at 30 days; and 3BR bioregulator at seven days + bioregulator and foliar fertilization at 20 days + ethylene inhibitor and bioregulator at 30 days. Two blocks were used, with nine replicates each.

\section{Table 1}

Composition and concentration of bioregulators in Pennisetum purpureum cv. Napier

Bioregulator

Indolebutyric acid

Kinetin

Gibberellic acid

Foliar fertilization

Ethylene inhibitor
Concentration

$50 \mathrm{mg} \mathrm{L}^{-1}$

$90 \mathrm{mg} \mathrm{L}^{-1}$

$90 \mathrm{mg} \mathrm{L}^{-1}$

$100 \mathrm{~g} \mathrm{~L}^{-1}$ of $\mathrm{N} ; 90 \mathrm{~g} \mathrm{~L}^{-1}$ of $\mathrm{Ca} ; 100 \mathrm{mg} \mathrm{L}^{-1}$ of $\mathrm{B}$

$65 \mathrm{~g} \mathrm{~L}^{-1}$ of $\mathrm{N} ; 2,000 \mathrm{mg} \mathrm{L}^{-1}$ of $\mathrm{Co} ; 3,000 \mathrm{mg} \mathrm{L}^{-1}$ of $\mathrm{Mo}$ 
Table 2

Application design of the experimental protocols

\begin{tabular}{|c|c|c|c|}
\hline \multirow{2}{*}{ Protocol' } & \multicolumn{3}{|c|}{ Time of application } \\
\hline & Seven days & 20 days & 30 days \\
\hline Control & - & - & - \\
\hline $1 \mathrm{BR}$ & BR & - & - \\
\hline 2BR & BR & $B R+F F$ & - \\
\hline 2BR2 & BR & $\mathrm{BR}+\mathrm{FF}$ & El \\
\hline 3BR & BR & $\mathrm{BR}+\mathrm{FF}$ & $\mathrm{BR}+\mathrm{El}$ \\
\hline
\end{tabular}

'Control: no application of bio-growth regulators; 1BR: bioregulator at seven days; 2BR: bioregulator at seven days and biostimulant and foliar fertilization at 20 days; 2BR2: bioregulator at seven days, biostimulant and foliar fertilization at 20 days and ethylene inhibitor at 30 days; 3BR: bioregulator at seven days, biostimulant and foliar fertilization at 20 days and ethylene inhibitor and bioregulator at 30 days.

Spraying was performed in the early morning with a Stihl sprayer (20-L capacity with pressure vessel) equipped with a manometer to monitor the pressure. The operator was trained to walk $4 \mathrm{~m}$ in $12 \mathrm{~s}$ (timed), using a spraying pressure of 2 atm, to apply a mixture volume of $500 \mathrm{~mL}$ in each plot.

The rates established in the 500$\mathrm{mL}$ spray volume, for each plot $\left(16 \mathrm{~m}^{2}\right)$, were $0.32 \mathrm{~mL}$ for bioregulators; $6.4 \mathrm{~mL}$ for the foliar fertilizer and $1.28 \mathrm{~mL}$ for the ethylene inhibitor, which corresponded to $250 \mathrm{~mL}$ $\mathrm{ha}^{-1}$ of bioregulators, $5.0 \mathrm{~L} \mathrm{ha}^{-1}$ of foliar fertilizer and $1.0 \mathrm{~L} \mathrm{ha}^{-1}$ of ethylene inhibitor. In Pennisetum purpureum cv. Napier, there is no recommended rate or stage of development for the application of biostimulants. Therefore, the rates of biostimulants and micronutrients were determined based on the manufacturer's recommendation for the maize crop.

Two clumps were chosen and marked in the center of the plot 10 days after the uniformity cut, to count the initial tillers. On the harvest day, the tillers were counted and internode length and stem height were measured with a measuring tape. Clump height (up to the fold of the leaf) and the average number of internodes per plant were measured using a measuring tape, while diameter was measured with a caliper. At harvest time, each clump was taken to separate stems, leaves and dead material. At 10 days of regrowth after cutting the grass, the postharvest tiller count was performed.

On June 10, 2017, the grass was harvested after 70 days of regrowth, at $15 \mathrm{~cm}$ above the ground, to measure yield. The grass was collected from two linear meters from the two central rows of the plot, totaling four linear meters. The material was weighed and the yield per hectare was calculated from the obtained weight. Subsequently, the grass was ground to $3-5-\mathrm{cm}$ particles using a stationary forage machine.

The samples were pre-dried in a forcedair oven at $55^{\circ} \mathrm{C}$ for $72 \mathrm{~h}$ and then ground in a knife mill with a 1-mm sieve for chemical analysis. The dry matter (DM) and ether extract (EE) contents were determined according to the methodology of the Association of Official 
Analytical Chemists [AOAC] (1995); crude protein (CP), by the Kjeldhal method; and neutral detergent fiber (NDF), acid detergent fiber (ADF), lignin, cellulose, hemicellulose, mineral matter and neutral detergent insoluble nitrogen compounds (NDIP), according to Van Soest, Robertson and Lewis (1991). Total carbohydrates (TC) were calculated using the equation proposed by Sniffen, O'Connor and Van Soest (1992): TC = $100-(\% \mathrm{CP}+\% \mathrm{EE}+$ $\%$ Ash). Non-fibrous carbohydrates (NFC) were calculated by the equation described by Hall, Hoover, Jennings and Webster (1999): NFC $=100-(\% \mathrm{CP}+\% \mathrm{EE}+\% \mathrm{NDF}+\%$ Ash $)$. Total digestible nutrients (TDN) were estimated by the equation proposed by Cappelle, Valadares, Silva and Cecon (2001): TDN = 83.79 - 0.4171NDF.

The rumen degradability of DM was determined by the methodology proposed by Mehez and Orskov (1977), after grinding the material in a 5-mm sieve in a knife mill. Then, 0.5 $g$ was placed in non-woven fabric ("TNT") bags with dimensions of $5 \times 5 \mathrm{~cm}$, inside nylon bags, and incubated in the rumen of two fistulated cattle. The incubation times of $0,6,12,24,48$ and $72 \mathrm{~h}$ were evaluated. After washing, the material was analyzed for the DM content, according to AOAC (1995); CP content by the Kjeldhal method; and NDF content according to Van Soest et al. (1991).

Dry matter disappearance data were fitted by nonlinear regression, which predicts the potential degradability (PD) of feedstuffs using the model proposed by Mehez and Orskov (1977), as follows: PD = a $+b\left(1-e^{-c t}\right)$, where "a" is the soluble fraction; $\mathrm{b}$, the potentially degradable fraction; and $\mathrm{c}$, the degradation rate of fraction " $b$ ". Effective degradability (ED) was calculated according to the mathematical model proposed by Orskov and McDonald (1979): $E D=a+\left(\left(b^{*} c\right) /(c+k)\right)$. The equation was solved using $k$ values of 2 , 5 and $8 \% \mathrm{~h}^{-1}$, which represents the estimated rate of passage of solids in the rumen.

The experiment was laid out in a randomized-block design with 18 replicates per treatment and two blocks. Nine replicates were distributed per treatment in each block. The normality of the residuals and homogeneity of each variable were checked by Student's t test and the Shapiro-Wilk test. In the statistical model, the treatment (spraying protocol) was considered a fixed effect. Data were analyzed by analysis of variance, followed by comparison of means by Duncan's test at the $5 \%$ probability level, using the GLM procedure of SAS software (Statistical Analysis System [SAS], 2001).

\section{Results and Discussion}

The use of biostimulants sprayed together or alone did not change the yield of Pennisetum purpureum cv. Napier (Table 3). Fresh weight (FW) and DM yields were 66,143 and $11,462 \mathrm{~kg} \mathrm{ha}^{-1}$, respectively, which are close to the expected values for the species. Literature reports indicate FW yields of up to $80,000 \mathrm{~kg} \mathrm{ha}^{-1}$ and DM yields between 12,000 and $31,000 \mathrm{~kg} \mathrm{ha}^{-1}$ per harvest (Cardona, Rios, \& Peña, 2012; Stida et al., 2018; E. A. Ferreira, Abreu, Martinez, Braz, \& Ferreira, 2018). 
Table 3

Productivity, structural and morphological characteristics of the Pennisetum purpureum cv. Napier harvested at $\mathbf{7 0}$ days of age submitted to five spraying protocols of fertilization with bioregulators

\begin{tabular}{|c|c|c|c|c|c|c|c|c|}
\hline \multirow{2}{*}{ Item' } & \multicolumn{5}{|c|}{ Spraying protocols" } & \multirow{2}{*}{ Mean } & \multirow{2}{*}{$\mathrm{CV}^{\prime \prime \prime}$} & \multirow{2}{*}{ P-value } \\
\hline & Control & 1BR & 2BR & 2BR2 & 3BR & & & \\
\hline \multicolumn{9}{|c|}{ Productivity } \\
\hline $\mathrm{FW}\left(\mathrm{kg} \mathrm{ha}^{-1}\right)$ & 70,101 & 63,069 & 61,630 & 71,241 & 64,675 & 66,1552 & 23.21 & 0.2561 \\
\hline DM (kg ha-1) & 12,246 & 11,213 & 10,661 & 12,274 & 10,917 & 11,462 & 24.18 & 0.3024 \\
\hline \multicolumn{9}{|c|}{ Structural characteristics } \\
\hline $\mathrm{CH}(\mathrm{m})$ & $2.35^{c}$ & $2.42^{\mathrm{bc}}$ & $2.47^{\mathrm{b}}$ & $2.47^{b}$ & $2.58^{a}$ & 2.46 & 7.53 & 0.0016 \\
\hline$A C(m)$ & $1.67^{c}$ & $1.71^{\mathrm{bc}}$ & $1.78^{\mathrm{ab}}$ & $1.78^{\mathrm{ab}}$ & $1.83^{\mathrm{a}}$ & 1.75 & 10.59 & 0.0194 \\
\hline DS (cm) & 1.42 & 1.39 & 1.41 & 1.46 & 1.40 & 1.42 & 22.94 & 0.9211 \\
\hline IN (n) & 6.91 & 6.76 & 6.72 & 7.09 & 7.12 & 6.92 & 14.15 & 0.3352 \\
\hline $\mathrm{IL}(\mathrm{cm})$ & 19.89 & 20.30 & 20.49 & 20.33 & 20.78 & 20.35 & 9.40 & 0.4214 \\
\hline \multicolumn{9}{|c|}{ Morphological characteristics } \\
\hline Leaf (g kg-1 DM) & 381.9 & 370.6 & 342.0 & 360.5 & 365.6 & 364.2 & 14.38 & 0.5659 \\
\hline Stem ( $\left.\mathrm{g} \mathrm{kg}^{-1} \mathrm{DM}\right)$ & 602.6 & 599.6 & 642.9 & 621.9 & 615.1 & 617.5 & 7.46 & 0.3354 \\
\hline $\mathrm{SM}\left(\mathrm{g} \mathrm{kg}^{-1} \mathrm{DM}\right)$ & 15.5 & 29.8 & 15.1 & 17.7 & 19.3 & 18.3 & 9.36 & 0.6232 \\
\hline
\end{tabular}

IFW: fresh weight; DM: dry matter; $\mathrm{CH}$ : canopy height; SH: stem height; DS: diameter of stem; IN: internode number; IL: Internode length; SM: senescent material.

"1BR: bioregulator at seven days; 2BR: bioregulator at seven days and biostimulant and foliar fertilization at 20 days; 2BR2: bioregulator at seven days, biostimulant and foliar fertilization at 20 days and ethylene inhibitor at 30 days; 3BR: bioregulator at seven days, biostimulant and foliar fertilization at 20 days and ethylene inhibitor and bioregulator at 30 days.

"'CV: coefficient of variation.

Means followed by the same letter on the line do not differ by Duncan's test $(P<0.05)$.

Biostimulants are recommended to improve plant yield as a result of the increase in nitrogen, carbon and sulfur assimilation (Jannin et al., 2012, 2013), which consequently increases photosynthesis, facilitating ionic transport and stress responses and altering senescence (Khan et al., 2009; Parađiković et al., 2011). Climatic conditions such as light, rainfall and temperature are lower in the fallwinter period, thus reducing photosynthetic activity, the main factor responsible for plant growth (Taiz \& Zeiger, 2017).

In agriculture, breeding currently provides a variety of plants (sorghum, maize, sugarcane) with resistance to water and nutritional deficits (Castro et al., 2017). The use of bioregulators in maize crops, in a strategy to increase yield, provided an increase of about $13 \%$ in grain yield (Cunha et al., 2016; Pricinotto et al., 2019). In sugarcane, yield increases can be slight or even exceed $20 \%$, depending on the responsiveness of each genotype (Silva et al., 2010; M. M. R. Ferreira et al., 2013). Breeding has been performed on Pennisetum purpureum cv. Napier, as seen for varieties Paraíso and BRS Capiaçu. However, these varieties are not widespread in national production systems. The variety evaluated 
here (Napier), in turn, is rather widespread. This led to its choice for study, based on the possibility of increasing the yield and nutritional value of this crop, which is already implemented in production systems (Pereira et al., 2016).

As described above, there is no recommended rate or stage of development for the application of biostimulants in Pennisetum purpureum cv. Napier; therefore, we used information on the maize crop. However, this crop receives great investment in technology and breeding, which provide highly productive varieties with different forms of resistance to environmental conditions. Unlike Pennisetum purpureum cv. Napier, the development stages of soybean, maize, wheat and rice crops are known, which makes it possible to manipulate each physiological phase with the use of biostimulants. Auxin acts synergistically with cytokinin, stimulating cell division, and studies have shown increased DM yield, according to the rate of the stimulant, in Urochloa brizantha cv. Marandu (Oliveira et al., 2019). Nevertheless, the same hormones can have an antagonistic effect on root initiation (Skoog \& Miller, 1957), which may explain the lack of effect of the biostimulants on the yield of Pennisetum purpureum cv. Napier.

Canopy height $(\mathrm{CH})$ and stem height (SH) were influenced by the biostimulant protocols (Table 3 ). The protocol with more bioregulator-based applications (3BR) resulted in the highest canopy (+9.78\%) relative to control group. Likewise, $\mathrm{CH}$ was statistically highest in treatment 3BR, with a 9.58\% greater value in comparison with that achieved with control treatment. With the increase in frequency of application (2BR, 2BR2 and 3BR) stem height increased on average by $5.18 \%$ in comparison with the biostimulants applied only at seven days of regrowth. This was due to the synergism of the bioregulators with the natural plant hormones, coupled with the supply of sprayed nutrients. Biostimulants were sprayed at 7, 20 and 30 days after regrowth, a phase of intense vegetative growth and also a period of greater nutrient requirements. The positive action of the use of bioregulators via foliar spraying was also reported on the growth of common bean, tamarind and tobacco plants (Abrantes et al., 2011; Dantas et al., 2012; Ribeiro et al., 2017). Gibberellins favor cell growth and division, exerting a positive effect on the height of sprayed plants. By having similar physiological effects, auxins and cytokinins normally act in combination. These two classes of bioregulators form a hormonal balance that directs plant growth, in which low auxin/cytokinin ratios lead to the formation of shoots (Taiz \& Zeiger, 2017; Krouk, 2016). The bioregulator used in this study has $50 \mathrm{mg} \mathrm{L}^{-1}$ auxin to $90 \mathrm{mg} \mathrm{L}^{-1}$ cytokinin in its composition, a ratio considered low, which may explain the increase in the height of Pennisetum purpureum cv. Napier.

The use of biostimulants changed the chemical composition of Pennisetum purpureum cv. Napier (Table 4), specifically altering the levels of $\mathrm{CP}$ and neutral detergent insoluble protein (NDIP). The treatments affected the DM content, whose lowest value was obtained with the 3BR protocol. However, this treatment provided an increase in the CP and NDIP contents of Pennisetum purpureum cv. Napier compared with control group.

The improvement in the nutritional value of Pennisetum purpureum cv. Napier was due to the $17.55 \%$ increase in CP content, when we compare control group with the 3BR protocol. This response is due to the synergism between biostimulants and natural 
hormones, which provided a more efficient utilization of the nutrients available to the plant. The process of senescence involves the breakdown of chloroplasts, which contain up to $70 \%$ of the leaf protein. Carbon assimilation is replaced by the decomposition and conversion of chlorophyll, proteins and other macromolecules into exportable nutrients that are translocated, meeting other plant requirements (Taiz \& Zeiger, 2017).

Auxins cause a decrease in the expression of genes responsible for leaf senescence, as does unconjugated gibberellin (GA4 and GA7), when available (Castro et al., 2017; Taiz \& Zeiger, 2017). The greater cytokinin uptake causes the transfer RNA (tRNA) to bind to the ribosome-messenger complex and influences the formation and function of several transfer RNAs and protein synthesis. Cytokinins maintain high protein and enzyme synthesis, delaying protein and chlorophyll degradation, in addition to reducing the respiratory rate of senescent leaves to preserve cell vigor (Castro et al., 2017).

\section{Table 4}

DM content ( $\left.\mathrm{g} \mathrm{kg}^{-1}\right)$ and chemical composition ( $\mathrm{g} \mathrm{kg}^{-1}$ of DM) of the Pennisetum purpureum cv. Napier harvested at $\mathbf{7 0}$ days of age submitted to five spraying protocols of fertilization with bioregulators

\begin{tabular}{|c|c|c|c|c|c|c|c|c|}
\hline \multirow{2}{*}{ Item' } & \multicolumn{5}{|c|}{ Spraying protocols" } & \multirow{2}{*}{ Mean } & \multirow{2}{*}{$\mathrm{CV}^{\mathrm{III}}$} & \multirow{2}{*}{ P-value } \\
\hline & Control & 1BR & 2BR & 2BR2 & 3BR & & & \\
\hline DM & $174.7^{\mathrm{ab}}$ & $177.8^{\mathrm{a}}$ & $173.0^{\mathrm{ab}}$ & $172.3^{\mathrm{ab}}$ & $168.8^{b}$ & 173.3 & 6.54 & 0.0453 \\
\hline $\mathrm{CP}$ & $100.8^{b}$ & $104.9^{a b}$ & $113.0^{\mathrm{ab}}$ & $116.9^{a b}$ & $118.5^{a}$ & 110.6 & 19.03 & 0.0374 \\
\hline NDIP & $510.0^{\mathrm{b}}$ & $524.0^{\mathrm{ab}}$ & $570.0^{\mathrm{ab}}$ & $566.0^{\mathrm{ab}}$ & $619.0^{a}$ & 557.0 & 22.54 & $<0.0001$ \\
\hline EE & 184.2 & 180.0 & 187.3 & 183.0 & 161.2 & 179.1 & 32.20 & 0.3245 \\
\hline $\mathrm{TC}$ & 776.9 & 776.1 & 769.7 & 772.3 & 769.9 & 773.1 & 3.18 & 0.2652 \\
\hline $\mathrm{NDF}_{\mathrm{AP}}$ & 648.8 & 651.7 & 645.3 & 649.3 & 652.3 & 649.5 & 8.08 & 0.5623 \\
\hline ADF & 435.2 & 429.0 & 437.9 & 438.5 & 432.4 & 434.6 & 6.15 & 0.1245 \\
\hline HEM & 212.6 & 220.4 & 207.2 & 213.2 & 217.9 & 214.3 & 25.65 & 0.1734 \\
\hline CEL & 408.3 & 402.7 & 409.0 & 409.8 & 408.1 & 407.7 & 7.26 & 0.5176 \\
\hline LIG & 25.0 & 25.1 & 26.3 & 24.9 & 25.7 & 25.4 & 33.49 & 0.2922 \\
\hline NFC & 120.9 & 122.4 & 125.2 & 125.5 & 110.0 & 121.1 & 44.89 & 0.2042 \\
\hline Ash & 99.5 & 99.2 & 96.8 & 99.4 & 102.2 & 99.5 & 10.88 & 0.1649 \\
\hline NDIA & 50.6 & 46.7 & 47.9 & 48.4 & 44.0 & 47.5 & 35.28 & 0.3195 \\
\hline TDN & 500.4 & 562.4 & 567.5 & 568.1 & 565.7 & 566.9 & 3.83 & 0.1523 \\
\hline
\end{tabular}

'DM: dry matter; CP: crude protein; NDIP: neutral detergent insoluble protein; EE: ether extract; TC: total carbohydrates; $\mathrm{NDF}_{\mathrm{AP}}$ : neutral detergent fiber corrected for ash and protein; ADF: acid detergent fiber; HEM: hemicellulose; CEL: cellulose; LIG: lignin; NFC: non-fibrous carbohydrates; NDIA: neutral detergent insoluble ash; TDN: total digestible nutrients.

"1BR: bioregulator at seven days; 2BR: bioregulator at seven days and biostimulant and foliar fertilization at 20 days; 2BR2: bioregulator at seven days, biostimulant and foliar fertilization at 20 days and ethylene inhibitor at 30 days; 3BR: bioregulator at seven days, biostimulant and foliar fertilization at 20 days and ethylene inhibitor and bioregulator at 30 days.

II'CV: coefficient of variation.

Means followed by the same letter on the line do not differ by Duncan's test $(P<0.05)$. 
The gene expression for ethylene synthesis increases exponentially when chlorophyll decline begins with the progression of leaf aging. In the composition of the ethylene inhibitor used in the protocols, in addition to $65 \mathrm{~g} \mathrm{~L}^{-1}$ nitrogen, $65 \mathrm{~g} \mathrm{~L}^{-1} \mathrm{P}_{2} \mathrm{O}_{5^{\prime}}$ $13 \mathrm{~g} \mathrm{~L}^{-1}$ sulfur and $39 \mathrm{~g} \mathrm{~L}^{-1}$ molybdenum, it also contains $26 \mathrm{~g} \mathrm{~L}^{-1}$ cobalt. According to Taiz and Zeiger (2017), the cobalt ion $\left(\mathrm{Co}^{2+}\right)$ is an inhibitor of the synthesis pathway of ethylene, which is synthesized from methionine. This ion blocks the conversion of ACC synthase into ethylene, performed by the enzyme ACC oxidase, the last step in ethylene biosynthesis. This action temporarily reduces ethylene production. The biosynthesis and transport of auxin and cytokinins are stimulated and, in response, there is an increase in the activity of ethylene-producing enzymes. When there is a reduction in available nitrogen, in turn, plant growth decreases along with active cytokinins, and auxin is translocated from the plant shoots to be accumulated in the roots (Krouk, 2016). Thus, the 3BR protocol may moderately favor the supply of bioregulators, nitrogen and ethylene inhibitor to stimulate the physiology of Pennisetum purpureum cv. Napier, resulting in greater accumulation of CP.

In ruminant diets, when the $\mathrm{CP}$ contents of grasses do not reach the minimum value of $7 \%$, rumen microbial activity is limited, compromising the use of fibrous energy substrates and, consequently, animal performance (Minson, 1990) Thus, the forage seasonality in the tropical climate results in a drop in production and nutritional value during the fall-winter transition period, which is caused by environmental limitations such as rainfall, light and temperature. In this scenario, the use of biostimulants represents another tool to overcome this problem, as they are able to modulate the physiology of Pennisetum purpureum cv. Napier while maintaining its metabolic rate.

In ruminant feeding, it is essential to provide forages of high nutritional value. However, degradability influences nutrient utilization and the extent to which nutritional requirements for maintenance and production are met. In the evaluation of applications of biostimulant protocols on the degradability of Pennisetum purpureum cv. Napier, there was an improvement in the effective degradability of DM and NDF and an increase in the potential degradability of NDF (Table 5). The biostimulants had no effect on the potential or effective degradability of DM considering a passage rate of $2 \% \mathrm{~h}^{-1}$. However, the 3BR treatment showed higher (+7.14\%) effective degradability considering the rates of 5 and $8 \% \mathrm{~h}^{-1}(\mathrm{P}<0.0001)$. The degradability of NDF was also affected by the treatments, with the 2BR2 protocol significantly increasing its potential degradability. When considering lowmedium- and high-intake animals, the 2BR protocol provided an increase $(P<0.0001)$ in effective degradability in comparison with the other treatments. 
Table 5

In situ Ruminal parameters of DM and NDF ( $\mathrm{g} \mathrm{kg}^{-1}$ of DM) of the Pennisetum purpureum cv. Napier harvested at $\mathbf{7 0}$ days of age submitted to five spraying protocols of fertilization with bioregulators

\begin{tabular}{|c|c|c|c|c|c|c|c|}
\hline \multirow{2}{*}{ Item' } & \multicolumn{5}{|c|}{ Spraying protocols" } & \multirow{2}{*}{$\mathrm{CV}^{\prime \prime \prime}$} & \multirow{2}{*}{ P-value } \\
\hline & Control & 1BR & 2BR & 2BR2 & 3BR & & \\
\hline \multicolumn{8}{|c|}{ Degradability of DM } \\
\hline PD & 688.8 & 706.0 & 680.2 & 678.9 & 686.8 & 6.325 & 0.4512 \\
\hline ED2\% & 513.5 & 522.4 & 508.6 & 514.7 & 526.5 & 4.741 & 0.4535 \\
\hline ED5\% & $370.8^{b}$ & $374.4^{b}$ & $370.0^{b}$ & $382.2^{\mathrm{ab}}$ & $395.9^{a}$ & 4.920 & $<0.0001$ \\
\hline ED8\% & $304.3^{b}$ & $307.7^{b}$ & $304.0^{b}$ & $316.2^{b}$ & $330.3^{a}$ & 5.951 & $<0.0001$ \\
\hline \multicolumn{8}{|c|}{ Degradability of NDF } \\
\hline PD & $576.1^{c}$ & $595.7^{b}$ & $594.2^{\mathrm{b}}$ & $614.6^{a}$ & $592.7^{\mathrm{b}}$ & 2.805 & $<0.0001$ \\
\hline ED2\% & $471.2^{\mathrm{b}}$ & $476.5^{b}$ & $502.5^{a}$ & $478.3^{b}$ & $476.6^{b}$ & 3.585 & $<0.0001$ \\
\hline ED5\% & $377.2^{\mathrm{bc}}$ & $379.8^{\mathrm{bc}}$ & $423.5^{\mathrm{a}}$ & $368.2^{c}$ & $379.8^{b}$ & 6.525 & $<0.0001$ \\
\hline ED8\% & $335.4^{\mathrm{b}}$ & $329.5^{b}$ & $394.3^{a}$ & $318.8^{c}$ & $330.0^{b}$ & 8.694 & $<0.0001$ \\
\hline
\end{tabular}

'DP: potential degradability; ED2\%: effective degradability at passage rate of $0.02 \mathrm{~h}^{-1}$; ED5\%: effective degradability at passage rate of $0.05 \mathrm{~h}^{-1}$; ED8\%: effective degradability at passage rate of $0.08 \mathrm{~h}^{-1}$.

"1BR: bioregulator at seven days; 2BR: bioregulator at seven days and biostimulant and foliar fertilization at 20 days; 2BR2: bioregulator at seven days, biostimulant and foliar fertilization at 20 days and ethylene inhibitor at 30 days; 3BR: bioregulator at seven days, biostimulant and foliar fertilization at 20 days and ethylene inhibitor and bioregulator at 30 days.

"'CV: coefficient of variation.

Means followed by the same letter on the line do not differ by Duncan's test $(P<0.05)$.

Biostimulants can cause structural changes in plant tissues, increasing degradability. The bioregulator used in the tested protocols is composed of three plant regulators: gibberellic acid - GA3 (gibberellin), indolebutyric acid - IBA (auxin analogue) and kinetin (cytokinin). Gibberellins stimulate the synthesis of enzymes such as $\alpha$-amylase, which induce a reduction in osmotic potential in the vacuole through the formation of glucose from starch, causing an influx of water, which leads to cell growth. Auxins, in turn, act in the synthesis of messenger RNA, inducing the formation of enzymes such as proteases, which results in the synthesis of tryptophan and formation of indole acetic acid (IAA), a precursor of auxin. Hydrolases and lipases, which act on polysaccharides or glycopeptides, are also produced, disrupting the bonds between the cellulose microfibrils that make up the cell wall. This disruption causes an increase in plasticity and irreversible deformation of the cell wall (Castro et al., 2017).

The synergism of the natural physiology of Pennisetum purpureum cv. Napier and the three applications of bioregulators acts to modify the cell structure. Exogenous application of cytokinins, through signaling and binding with RNA, influences the increase in protein and enzyme synthesis. Thus, there is a delay in the degradation of chloroplasts and chlorophyll, in addition to a decrease in the respiratory rate of senescent leaves, preserving cell vigor (Castro et al., 2017). Coupled with these factors, the nutritional 
uptake of nitrogen, phosphorus, sulfur and cobalt through the leaves promotes the production and maintenance of chloroplasts (Taiz \& Zeiger, 2017). This information is directly related to the increase in the nutritional quality of Pennisetum purpureum cv. Napier under the 3BR protocol, which improved effective degradability. Improvements in the nutritional quality of tropical forages such as Pennisetum purpureum cv. Napier have been sought due to the characteristic protein deficit of these grasses (Fioreli et al., 2018; Faria, Morenz, Paciullo, Lopes, \& Gomide 2018; Galindo, Buzetti, Teixeira, Dupas, \& Carvalho, 2018; Emerenciano, Bezerra, França, Aguiar, \& Difante, 2019).

The synergism between bioregulators and the supply of macro-and micronutrients stimulates plant metabolism, keeping tissues growing and favoring degradability (Wilson, 1993). Overall, the biostimulant protocols applied to Pennisetum purpureum cv. Napier provided higher NDF degradability than control (Table 5), despite maintaining the lignin concentration unchanged. The results reveal the lower potential degradability of NDF in control compared with all other protocols.

As noted, the use of biostimulants for Pennisetum purpureum cv. Napier proved to be promising, since the results indicate a clearly positive action of foliar fertilization and the ethylene inhibitor associated with bioregulators. As previously discussed, these results can be explained by the fact that bioregulators stimulate growth, which, coupled with fertilization with macro-and micronutrients and cobalt (ethylene inhibitor), delays plant senescence (Nardi, Pizzeghello, Schiavon, \& Ertani, 2016; Castro et al., 2017; Taiz \& Zeiger, 2017).

\section{Conclusion}

Despite not influencing yield, biostimulant protocols increase the canopy and stem heights and the crude protein content of Pennisetum purpureum cv. Napier harvested at 70 days of regrowth. The application of bioregulator associated with foliar fertilization and ethylene inhibitor improves the effective degradability of dry matter and neutral detergent fiber and the potential degradability of neutral detergent fiber in this forage.

\section{References}

Abrantes, F. L., Sá, M. E., Souza, L. C. D., Silva, M. P., Simidu, H. M., Andreotti, M.,... Arruda, N. (2011). Uso de regulador de crescimento em cultivares de feijão de inverno. Pesquisa Agropecuária Tropical, 41(2), 148-154. doi: 10.5216/pat.v41i2.8287

Association of Official Analytical Chemists (1995). Official methods of analysis (16nd ed.). Arlington, VA: AOAC.

Brennecke, K., Ferraz, F. M., \& Simões, T. R. (2015). Germinação de sementes de Brachiaria decumbens sob diferentes concentrações de biorregulador. Revista Acadêmica Ciência Animal, 13, 145-151. doi: 10.7213/academica.13.FC.AO15

Caldas, L. S., Haridasan, P., \& Ferreira, M. E. (1990). Meios nutritivos. In A. C. Torres, L. S. Caldas, Técnicas e aplicações da cultura de tecidos de plantas (pp. 37-70). Brasília: ABCTP; Embrapa CNPH.

Cappelle, E. R., Valadares, S. C., Fo., Silva, J. F. C., \& Cecon, P. R. (2001). Estimativas do valor energético a partir de características químicas e bromatológicas dos alimentos. Revista Brasileira de Zootecnia, 30(6), 
1837-1856. doi: 10.1590/S1516-359820 01000700022

Cardona, E. M., Rios, L. A., \& Peña, J. D. (2012). Disponibilidad de Variedades de Pastos y Forrajes como Potenciales Materiales Lignocelulósicos para la Producción de Bioetanol en Colombia. Información Tecnológica, 23(6), 87-96. doi: 10.4067/ S0718-07642012000600010

Castro, P. R. C., Carvalho, M. E. A., Mendes, A. C. C. M., \& Angelini, B. G. (2017). Manual de estimulantes vegetais: nutrientes, biorreguladores, bioestimulantes, bioativadores, fosfitos e biofertilizantes na agricultura tropical. Ouro Fino, MG: Agronômica Ceres.

Chitarra, M. I. F., \& Chitarra, A. B. (2005). Póscolheita de frutos e hortaliças: fisiologia e manuseio (2a ed. rev. atual. e ampl.). Lavras: UFLA.

Cunha, R. G., Lima, S. F., Alvarez, R. D. C. F., Simon, C. A., \& Contardi, L. M. (2016). Arranjo espacial e biorregulador de crescimento na produtividade de milho. Revista de Ciências Agroambientais, 14(2), 24-31. doi: 10.5327/rcaa.v14i2.1263

Dantas, A. C. V. L., Queiroz, J. M. O., Vieira, E. L., \& Almeida, V. O. (2012). Effect of gibberellic acid and the biostimulant stimulate ${ }^{\circledR}$ on the initial growth of tamarind. Revista Brasileira de Fruticultura, 34(1), 8-14. doi: 10.1590/S0100-29452012000100004

Emerenciano, J. V., Neto, Bezerra, M. G. D. S. França, A. F. D., Aguiar, E. M. D., \& Difante, G. D. S. (2019). Características estruturais e produtivas em híbridos intraespecíficos e interespecíficos de capim-elefante. Ciência Animal Brasileira, 20(e-46788), 1-11. doi: 10.1590/1809-6891v20e-46788

Empresa Brasileira de Pesquisa Agropecuária (2006). Sistema Brasileiro de Classificação de Solos (2a ed.). Rio de Janeiro: Embrapa Solos.

Faria, M. B., Morenz, M. J. F., Paciullo, D. S. C., Lopes, F. C. F., \& Gomide, C. A. M. (2018). Growth and bromatological characteristics of Brachiaria decumbens and Brachiaria ruziziensis under shading and nitrogen. Revista Ciência Agronômica, 49(3), 529536. doi: 10.5935/1806-6690.20180060

Ferreira, E. A., Abreu, J. G. D., Martinez, J. C., Braz, T. G. D. S., \& Ferreira, D. P. (2018). Cutting ages of elephant grass for chopped hay production. Pesquisa Agropecuária Tropical, 48(3), 245-253. doi: 10.15 90/1983-40632018v4851569

Ferreira, M. M. R., Ferreira, L. H. Z., \& Bolonhezi, A. C. (2013). Reguladores vegetais aplicados no sulco de plantio em cultivares de canade-açúcar. Scientia Agraria, 14(2), 59-64. doi: 10.5380/rsa.v14i2.40891

Fioreli, A. B., Ziech, M. F., Fluck, A. C., Gerei, J. C., Col, D., Berns, L., \& Costa, O. D. (2018). Valor nutritivo de gramíneas do gênero Cynodon consorciadas com amendoim forrageiro. Arquivo Brasileiro de Medicina Veterinária e Zootecnia, 70(6), 1970-1978. doi: 10.1590/1678-4162-10048

Galindo, F. S., Buzetti, S., Teixeira, M. C. M., Fo., Dupas, E., \& Carvalho, F. D. C. (2018). Manejo da adubação nitrogenada no capim-mombaça em função de fontes e doses de nitrogênio. Revista de Ciências Agrárias, 41(4), 31-40. doi: 10.19084/ RCA18131

Hall, M. B., Hoover, W. H., Jennings, J. P., \& Webster, T. K. M. (1999). A method for partitioning neutral detergent-soluble carbohydrates. Journal of Science Food and Agriculture, 79(15), 20792086. doi: 10.1002/(SICl)1097-0010 (199912)79:15<2079::AID-JSFA502> 3.0.CO; $2-Z$ 
Harper, J. E. (1984). Uptake of organic nitrogen forms by roots and leaves. In R. D. Hauck (Ed.), Nitrogen in crop production (pp. 165-170). Wisconsin: American Society of Agronomy.

Instituto Nacional de Meteorologia (2019). Estações e dados/dados metereológicos. Recuperado de http://www.inmet.gov.br/ portal/index.php?r=estacoes/estacoes Automaticas

Jannin, L., Arkoun, M., Etienne, P., Laîné, P., Goux, D., Garnica, M., \& Houdusse, F. (2013). Brassica napus growth is promoted by Ascophyllum nodosum seaweed extract: microarray analysis and physiological characterization of N, C, and S metabolisms. Journal of Plant Growth Regulation, 32(1), 31-52. doi: 10.1007/ s00344-012-9273-9

Jannin, L., Arkoun, M., Ourry, A., Laîné, P., Goux, D., Garnica, M., \& Houdusse, F. (2012). Microarray analysis of humic acid effects on Brassica napus growth: involvement of N, C and S metabolisms. Plant and Soil, 359(1-2), 297-319. doi: 10.1007/s11104012-1191-x

Khan, W., Rayirath, U. P., Subramanian, S., Jithesh, M. N., Rayorath, P., Hodges, D. M., \& Prithiviraj, B. (2009). Seaweed extracts as biostimulants of plant growth and development. Journal of Plant Growth Regulation, 28(4), 386-399. doi: 10.1007/ s00344-009-9103-x

Krouk, G. (2016). Hormones and nitrate: a twoway connection. Plant Molecular Biology, 91(6), 599-606. doi: 10.1007/s11103016-0463-x

Mehez, A. Z., \& Orskov, E. R. (1977). A study of the artificial fibre bag technique for determining the digestibility of feeds in the rumen. Journal of Agricultural Science, 88(3), 645-650. doi: 10.1017/ S0021859600037321
Minson, D. J. (1990). Forage in ruminant nutrition. San Diego: Academic Press.

Morais, R. F., Souza, B. J., Leite, J. M., Soares, L. H. B., Alves, B. J. R., Boddey, R. M., \& Urquiaga, S. (2009). Elephant grass genotypes for bioenergy production by direct biomass combustion. Pesquisa Agropecuária Brasileira, 44(2), 133-140. doi: 10.1590/S0 100-204X2009000200004

Mortate, R. K., Nascimento, E. F., Gonçalves, E. G. S., \& Lima, M. W. P. (2018). Resposta do milho (Zea mays L.) à adubação foliar e via solo de nitrogênio. Revista de Agricultura Neotropical, 5(1), 1-6. doi: 10.32404/rean. v5i1.2202

Nardi, S., Pizzeghello, D., Schiavon, M., \&Ertani,A. (2016). Plant biostimulants: physiological responses induced by protein hydrolyzedbased products and humic substances in plant metabolism. Scientia Agricola, 73(1), 18-23. doi: 10.1590/0103-9016-20150006

Oliveira, W. F., Lima, E. M., Gomes, D. I., Alves, K. S., Santos, P. M., Azevedo, G. S., \& Mezzomo, R. (2019). Agronomic performance of Marandu grass treated with plant growth biostimulants in the Amazon biome. Arquivo Brasileiro de Medicina Veterinária e Zootecnia, 71(2), 603-612. doi: 10.1590/1678-4162-10369

Orskov, E. R., \& McDonald, I. (1979). The estimation of protein degradability in the rumen from incubation measurements weighted according to rate of passage. Journal of Agricultural Science, 92(2), 499503. doi: $10.1017 / S 0021859600063048$

Parađiković, N., Vinković, T., Vinković Vrček, I., Žuntar, I., Bojić, M., \& Medić-Šarić, M. (2011). Effect of natural biostimulants on yield and nutritional quality: an example of sweet yellow pepper (Capsicum annuum L.) plants. Journal of the Science of Food 
and Agriculture, 91(12), 2146-2152. doi: 10.1002/jsfa.4431

Pereira, A. V., Ledo, F. D. S., Morenz, M. J. F., Leite, J. L. B., Brighenti, A. M., Martins, C. E., \& Machado, J. C. (2016). BRS Capiaçu: cultivar de capim-elefante de alto rendimento para produção de silagem. (Comunicado Técnico). Juiz de Fora: EMBRAPA Gado de Leite.

Pricinotto, L. F., Zucareli, C., Ferreira, A. S., Spolaor, L. T., \& Fonseca, I. C. D. B. (2019). Yield and biometric characteristics of maize submitted to plant population and trinexapac-ethyl doses. Revista Caatinga, 32(3), 667-678. doi: 10.1590/ 1983-21252019v32n311rc

Ribeiro, L. O., Vieira, E. L., Girardi, E. A., Carvalho, E. V., \& Ribeiro, M. O. (2017). Bioestimulante vegetal na produção de mudas de tabaco. Magistra, 29(2), 200-207. doi: https:// magistraonline.ufrb.edu.br/index.php/ magistra/article/view/431

Santos, F. A. P. (1993). Manejo de pastagens de capim-elefante. In A. M. Peixoto, J. C. Moura, \& V. P. Faria (Eds.), Volumosos para bovinos (pp. 1-20). Piracicaba, SP: FEALQ.

Silva, M. A., Cato, S. C., \& Costa, A. G. F. (2010). Produtividade e qualidade tecnológica da soqueira de cana-de-açúcar submetida à aplicação de biorregulador e fertilizantes líquidos. Ciência Rural, 40(4), 774-780. doi: 10.1590/S0103-84782010005000057

Skoog, F., \& Miller, C. O. (1957). Chemical regulation of growth and organ formation in plant tissue cultures in vitro. Symposia of the Society for Experimental Biology, 54(11), 118-130. Recovered from http:// europepmc.org/article/med/13486467
Sniffen, C. J., O'Connor, J. D., \& Van Soest, P. J. (1992). A net carbohydrate and protein system for evaluating cattle diets: IICarbohydrate and protein availability. Journal and Animal Science, 70(11), 35623577. doi: 10.2527/1992.70113562x

Statistical Analysis System Institute (2001). STAT user's guide: statistics version 8.2., Cary, NC: SAS Institute.

Stida, W. F., Daher, R. F., Viana, A. P., Vidal, A. K. F., Freitas, R. S., Silva, V. B.,... Furlani, E. P. (2018). Estimation of genetic parameters and selection of elephantgrass (Pennisetum purpureum Schumach) for forage production using mixed models. Chilean Journal of Agricultural Research, 78(2), 198-204. doi: 10.4067/S0718-5839 2018000200198

Taiz, L., \& Zeiger, E. (2017). Fisiologia e desenvolvimento vegetal (6a ed.). Porto Alegre: Artmed.

Van Soest, P. J., Robertson, J. B., \& Lewis, B. A. (1991). Methods for dietary fiber, neutral detergent fiber, and nonstarch polyssacarides in relation to animal nutrition. Journal of Dairy Science, 74(10), 3583-3597. doi: 10.3168/jds.S0022-0302 (91)78551-2

Wilson, J. R. (1993). Forage cell wall structure and digestibility. In Wilson J. R. (Ed.) Organization of forage plant tissues (pp. 1-32). Madison: American Society of Agronomy. 
